\title{
Linking the Performance of Entrepreneurial Universities to Technoparks and University Characteristics in Turkey
}

\author{
Tuzin Baycan $^{1}$, Gokcen Arkali Olcay ${ }^{2}$ \\ ${ }^{1}$ Istanbul Technical University, Istanbul, Turkey \\ ${ }^{2}$ Gebze Technical University, Gebze, Turkey
}

Received: 10 January 2020/Accepted: 2 December 2020

\begin{abstract}
Universities' third mission of knowledge commercialization imposes them a core role towards becoming entrepreneurial universities in the triple helix interacting with the government and industry. Entrepreneurial universities have crucial functions of providing entrepreneurial support infrastructure for innovation and engaging in the regional economy. Technoparks, in that sense, form an essential channel for universities to disseminate and commercialize the knowledge considering their geographical proximity and facilitating mechanisms. Measuring the performances of entrepreneurial universities and technoparks in quantitative metrics have been initiated by different government agencies in Turkey, which resulted in two different indices. The Most Entrepreneurial and Innovative University Index and the Performance Index for Technoparks track performances annually. Using the data provided by the two indices, this study explores how the technoparks' performance can be linked to the universities' scores in entrepreneurship and innovation, along with some university-specific characteristics and their interactions. The geographical proximity provided by the technoparks contributes to the performance of entrepreneurial universities. While the increasing university size has a negative effect on university entrepreneurial scores, the socio-economic development factor of the region positively contributes to the scores. Young universities are also found to benefit more from the large share of the graduate students of their student composition on university entrepreneurship and innovation scores.
\end{abstract}

Key words: Entrepreneurial universities in Turkey, technoparks, knowledge commercialization, geographical proximity, regional innovation

\section{Introduction}

Universities play a fundamental role in regional innovation and economic growth (Gunaseka ra 2006, Power, Malmberg 2008, Rasmussen et al. 2006) beyond their traditional missions of teaching and research that they were identified with so long in the history. The third mission of universities, contributing to the knowledge society, has its roots seeded in the pioneering work of Clark (1983). In his conceptual tool of the triangle of coordination, Clark (1983) views the place of universities from a broader perspective within the interactions of academic oligarchy, state authority, and market. This notion of interactions was later developed into the notion of the triple helix by Etzkowitz, Leydesdorff (1995). Even the triple helix model has further been transformed into the 
quadruple and quintuple models to incorporate the society's and environment's role (Carayannis, Campbell 2010). The government plays a key role in the interaction of the university and industry where the linear model of innovation based on the long-term contribution of the knowledge disseminated from the university to the economy is no longer the only option. Universities contribute to knowledge-based economic development via a spiral model of innovation commercializing and capitalizing the knowledge in both short and long terms (Etzkowitz, Leydesdorff 1995, Leydesdorff, Etzkowitz 1996).

Studying the ten to fifteen years of transformative developments in the five European institutions, Clark (1998) argues that universities are forced to change by the enormous demand overload surpassing their capacities, which they respond to transforming themselves into entrepreneurial universities. The notion of the entrepreneurial university is closely linked to the universities' third mission of evolving with new perspectives on technology transfer and commercialization and expanding to undertake a more direct role in regional development and innovation (Rasmussen et al. 2006). Etzkowitz (2004) punctuates the new mission of the entrepreneurial university acting as an economic entity interacting with the users of knowledge in capitalizing the knowledge.

The acceptance of knowledge commercialization as a third mission first came onto the development agenda in the U.S. in the 1980s and later spread to European countries in the 1990s (Baycan, Stough 2013, Charles, Howells 1992, van Geenhuizen 2010). While the first wave of knowledge commercialization in the 1980s was recognized by the establishment of traditional science parks where collaboration with existing industry emerged, the second wave in the 1990s saw a stronger focus on patenting/licensing and spinoffs as well as an increased involvement by students in commercialization (Rasmussen et al. 2006).

The third mission of engaging with the community (Rubens, Spiragelli 2017) is essential in getting the most out of all the stakeholders in the interacting spheres of the university, industry, and government. The engagement with the industry could take different forms, such as formal contracting, sponsoring research, transferring key personnel into employment, or access to university facilities (Monck et al. 1988, Quintas et al. 1992). Science and technology parks form another significant mechanism in engaging businesses with the academic knowledge on-site, which could have important regional implications (Lindelöf, Löfsten 2002). The geographical proximity provided by science parks could facilitate the transfer of knowledge, interactive learning, and innovation (Albahari et al. 2017).

The emergence of science and technology parks initiated a debate on how propertybased actions improve the economic and innovation performance of the university, industry, and the region (Link, Scott 2007). In the prior literature, scholars study how the science and technology park characteristics such as size, age, sectorial specialization, and geographical area affect the park tenants' innovation performance (Albahari et al. 2017, 2018, Liberati et al. 2016). Firms that are smaller in size benefit more from being located in science and technology parks on innovation performance (Huang et al. 2012). Besides, firms' innovation performance improves when the firms are located in less technologically developed areas or very new or longer established parks (Albahari et al. 2018).

Different terminology is used for technology parks in the literature. It is more common to use the term science park in Europe, the research park in the U.S., and the technology park (i.e., technopark) in Asia (Eckhardt, Shane 2003, Link, Scott 2007). While science, research, and technology parks are used interchangeably in the literature, we choose to use the term technopark within the context of our study. According to the legislation passed in 2001 in Turkey, technoparks are referred to as technology development zones representing the sites where academic, economic, and social structures are integrated and established within the close vicinity of the university, high-technology institute, or R\&D center for which they operate (General Directorate of Legislation Development 2001). Technoparks maintain companies that develop technology or software, carry out activities to transform a technological invention into commercial products, and use high or new technologies benefiting from the resources of the university or high-technology institute that they operate for.

On the other hand, entrepreneurial universities have come onto the agenda of the Higher Education Council of Turkey as well, and several programs, including regional 
development-oriented mission differentiation and specialization of Turkish universities, have been initiated recently. Two indices have been developed by the government agencies to track the performance of the entrepreneurial universities and the technoparks: the Most Entrepreneurial and Innovative University Index and the Performance Index for Technoparks. Universities that are smaller in size embrace the third mission differently in contributing to the regional economy and innovation (Rubens, Spiragelli 2017). Not all the universities get the expected benefits of the close geographical proximity of the technoparks. This study aims to understand how technoparks can be linked to the success of entrepreneurial universities from a regional perspective using the most recent data of the two indices. In understanding the link between the two, we also consider the effects of specific characteristics such as technopark age, university age, university size, the graduate program composition, and the socio-economic development index of the region.

In analyzing the third role of universities, Gunaseka ra (2006) highlights the variation in universities' performance of fulfilling the third mission in different regions. From the perspective of the Turkish regional innovation system, this study offers insights to regional policymakers, universities, and firms. Technoparks, with their proximity to universities, can help them to build entrepreneurial capacities and contribute to their innovation performances. However, other factors also promote entrepreneurial university performance a great deal. Young universities can benefit more from being research-oriented via investing in advanced degrees for more graduate-level students.

The rest of the paper is organized as follows. Section 2 investigates the geographical embeddedness of entrepreneurial universities, explicitly referring to the literature to understand how entrepreneurial universities commercialize knowledge and contribute to regional development via its linkages to technoparks. Section 3 describes the data and presents the empirical analyses of the research model. Section 4 offers a general discussion of the critical factors of the most entrepreneurial and innovative universities with concluding remarks and recommendations for future researches.

\section{Linking Entrepreneurial Universities to Technoparks}

The need for universities to transform themselves into a more entrepreneurial structure leads to the development of new kinds of relationships, governance systems, and a university-industry-public relations model. The model referred to as the triple helix (Etzkowitz, Leydesdorff 1995) indeed goes back to the pioneering study of Clark (1983) and visualizes the university as one of the main actors of the three - university, state, and the market - interacting with each other. Having high interactions with industry and government, entrepreneurial universities play an essential role in the process of knowledge commercialization and can contribute significantly to regional development.

The university dedicated to achieving the primary missions of teaching and research is needed to handle the new mission via the triple-helix or so-called partnership model carrying out the academic capabilities and resources outside the academic environment (Rubens, Spiragelli 2017). The universities undertaking the new mission are referred to as entrepreneurial universities resulting in an academic revolution in the field of higher education (Clark 1998, Etzkowitz 1983).

In fulfilling the third mission, entrepreneurial universities undertake new roles as

1. trainer (supply of skilled young graduates);

2. innovator (commercialization of academic knowledge);

3. partner (provision of technical know-how);

4. regional talent magnet (attractiveness of the region to talented academics and entrepreneurs);

5. facilitator (between private and public sectors) (Betts, Lee 2004).

In dealing with the new roles to become more entrepreneurial, universities face many challenges, from the perception of entrepreneurship and developing a shared institutional vision and consensus, to an organizational transformation or strong links with commercialization and income generation rather than education (Hannon 2013). However, the greatest challenge is how universities create effective environments for developing 
entrepreneurial capacities. Technoparks form a key channel in creating and enhancing the entrepreneurial capacities of the universities, in which there is a need to understand further how entrepreneurial universities are linked to technoparks.

\subsection{Entrepreneurial Universities and Knowledge Commercialization}

Three steps are defined towards an entrepreneurial university:

1. "the ability to set a strategic direction";

2. "a commitment to seeing that the knowledge developed within the university is put to use";

3. "the encouragement of start-ups based upon technologies that do not find a fit within existing firms" (Clark 1998, Etzkowitz 2016).

Therefore, universities develop their organizational capacities to work with firms, to transfer technologies, and to respond to societal changes. This proactive role that the universities take over leads to enhancing the innovation capabilities of the region where they are located. As a provider of human talent, entrepreneurial universities function as a seed-bed of new firms in the knowledge economy (Etzkowitz et al. 2000, Rasmussen et al. 2006).

An entrepreneurial university can be seen as "a university that develops a comprehensive internal system for the commodification and commercialization of knowledge" (Jacob et al. 2003, p. 1556). While undertaking the new role of knowledge commercialization opens up opportunities for the universities, it brings its own challenges. On the one hand, universities deal with increasing the extent of commercialization and finding ways to improve the economic contribution. On the other hand, they need to balance the commercialization and the other core activities (Rasmussen et al. 2006). To promote knowledge commercialization, universities go through various formal and informal initiatives. Building the infrastructure, such as establishing offices of patenting and licensing and incubator facilities for supporting new ventures, is one step that many universities take to become entrepreneurial universities (Rasmussen et al. 2006). Besides, legislation and policies are made at country levels to facilitate the commercialization of university research. However, infrastructure and policies are not sufficient for creating a culture of entrepreneurship, and making the individuals desire entrepreneurial activities is another important part of the knowledge commercialization.

Via the viewpoint of a researcher, Nilsson et al. (2010) explore why and how researchers engage in the commercialization process. Researchers desire to be academic entrepreneurs in alignment with the changing role of the university perceived in society as contributing to innovation and economic development as Nilsson et al. (2010) elaborates on. An academic entrepreneur is a university scientist, mostly a professor, sometimes a doctoral student or a post-doctoral researcher who establishes a company to commercialize the results of his/her research. Teaching at different universities, conducting consulting activities (Goldfarb, Henrekson 2003), conducting research projects (Louis et al. 1989), participating in patenting and licensing activities (Siegel et al. 2004), and founding new companies are considered academic entrepreneurship. The concept of academic entrepreneurship, illustrated by the activities that universities have carried out to contribute to commercialization in the regions they are in, has changed considerably in recent years. As a result of this change, universities are approaching the concept of academic entrepreneurship more strategically, and more stakeholders are involved (Siegel, Wright 2015). The supportive infrastructure that the university has and being located in a region where there are companies in need and capability to work with form the essential determinants of engaging in knowledge commercialization (Jensen, Thursby 2016, Melese 2006, Nilsson et al. 2010, Shane, Stuart 2002). The network links and trust between the researchers and industrial actors also affect knowledge commercialization (Nilsson et al. 2010).

In answering the question of how researchers transfer knowledge, Bercovitz, Feldmann (2006) conceptualize four different modes of knowledge transfer that are sponsored research, licenses, hiring of students particularly those working on sponsored projects, and spinoff 
firms. In addition to these, there are other informal mechanisms such as serendipity (Nilsson et al. 2010). In a similar vein, governance structures can also be described on a continuum where on one end, the knowledge can be commercialized and transferred through a Technology Transfer Office (TTO), and establishing a new organization with an entrepreneurial structure on the other (Bengtsson et al. 2009).

Using these structures, in the past years, universities have reached wider regions surrounding themselves by offering new programs and closer relationships with the business world (Boucher et al. 2003, Bramwell, Wolfe 2008, Duch-Brown et al. 2011, Goldstein, Renault 2004, Hudson 2006, Lazzeretti, Tavoletti 2005). Thus, the commercialization of knowledge has begun to be seen as an important stimulus of economic growth, particularly of development capability and boosting the economic performance of the regions (Agrawal 2001, Baycan, Stough 2013, Bok 2003, Etzkowitz 1990, 2002, Kochetkov et al. 2017, Litan et al. 2008, Viale, Etzkowitz 2010).

\subsection{Geographical Embeddedness of Entrepreneurial Universities}

The entrepreneurial potential of a regional university is determined by its engagement in a regional economic system (Kochetkov et al. 2017). An entrepreneurial university cannot be thought independent of its environment. As a key player in the regional economy, the entrepreneurial university needs to be evaluated from the point of its geographical embeddedness to the other players in the triple helix.

Agglomeration economies deal with the aggregation of various activities and different players in clusters, which is closely related to knowledge externalities. The cost of transmitting tacit knowledge increases with distance, supporting the argument that knowledge spillovers are geographically bounded (Audretsch 2002). When knowledge transfer is taking place, geographical proximity is crucial in exploiting the knowledge spillovers. Geographical proximity is linked to interactive learning and innovation as a facilitator of coordination and control in the prior literature of economic geography (Boschma 2005). There are four other dimensions of proximity identified in the literature - cognitive, organizational, social, and institutional - that need to be evaluated with geographical proximity (Torre, Gilly 2000). Boschma (2005) argues that geographical proximity is needed for better performance; however, it is not sufficient since geographical proximity facilitates interactive learning through other dimensions of proximity.

The geography of innovation activity matters more in industries where new knowledge is a crucial ingredient (Audretsch, Feldmann 2007). In considering the production and dissemination of new knowledge, spatial proximity plays a role in the transfer of knowledge between the university and the domestic industry, which does not happen to occur internationally (Kuttim 2016). According to the "university spillover thesis", the innovative activities of local entrepreneurial firms are positively affected by the knowledge spillovers from universities (Audretsch et al. 2012). While this effect is heterogeneous, which is likely to depend on the region and the university characteristics, the indirect and less tangible effects can be greater than the visualized. Classifying the entrepreneurial universities into three groups - potentially entrepreneurial, adaptive entrepreneurial, and ideal - Budyldina (2018) argues that entrepreneurial universities contribute to the region in terms of human capital attraction and detention, entrepreneurial capital, networking, and many other formal and informal means.

Entrepreneurial universities contribute and engage differently depending on their core strengths and modes of engagements, as there is no one-size-fits-all model (Benneworth et al. 2016, Sánchez-Barrioluengo 2014). While some contribute more towards commercialization activities such as producing spinoffs, others regionally engage with collaborative research, consulting, and contract research (Sánchez-Barrioluengo, Benneworth 2019).

Recent studies demonstrate that the implementation of the third mission at smaller universities generally promotes a much more regional or local approach to economic development (Rubens, Spiragelli 2017). The larger university ecosystem has been shown to have a significant impact on technology transfer while playing a critical role in providing resources and enhancing the competencies of faculty and students (Boh et al. 2016). University entrepreneurship ecosystems may differ according to their focus on internal versus external resources and connections. While some universities create a very structured 
network, others develop more organic entrepreneurship ecosystems, and other universities focus both internally and externally on creating connections and drawing in resources (Boh et al. 2016).

\subsection{Entrepreneurial Universities and Technoparks}

Dalmarco et al. (2018, p. 102) propose five distinct characteristics of entrepreneurial universities that are

1. having an entrepreneurial perspective,

2. developing external links,

3. giving access to university resources,

4. providing entrepreneurial support infrastructure for innovation,

5. carrying out scientific research.

While all are crucial for universities to develop entrepreneurial capabilities to support the third mission of knowledge commercialization and socio-economic development, we particularly focus on the fourth characteristic of innovation arrangement.

Technoparks form an important channel for universities to disseminate knowledge, especially considering their geographical proximity to universities to facilitate this process. In considering the triple-helix model, technology parks undertake a coordinating role among the various actors of research and development to collaborate and interact with each other (Jongwanich et al. 2014). Clustering firms within its body also triggers learning and innovation via reduced transaction costs of inter-firm activities (Fan, Scott 2003, Jongwanich et al. 2014). Science and technology parks form an essential means of commercializing knowledge for entrepreneurial universities.

Firms that reside in science parks are found to be associated with higher intangible outputs from innovative cooperation within the science and technology parks (VásquezUrriago et al. 2016). Science park firms having higher cooperation and links with universities (Löfsten, Lindelöf 2003, Malairaja, Zawdie 2008), might get more benefit from being located near and linked to the universities (Díez-Vial, Montoro-Sánchez 2016, Lindelöf, Löfsten 2002, Löfsten, Lindelöf 2003, Vásquez-Urriago et al. 2016).

\section{Research Model and Empirical Analyses}

Drawing attention to the rise of entrepreneurial universities in Turkey, we explore the contribution of being linked with a technopark, and the university and region-specific characteristics on the dependent most Entrepreneurial and Innovative Universities Index (EIUI) scores of the selected sample. We test the effects of variables including the university age, university size, the composition of the graduate (i.e., Masters and doctorate levels) students, the rankings of the technoparks, technopark age, and the socio-economic development index of the city on the dependent EIUI using a multiple regression model.

\subsection{Data and Variables}

\subsubsection{The Most Entrepreneurial and Innovative Universities Index}

'Entrepreneurial University of the Year' in the U.K.; 'Top Schools for Entrepreneurship' in the U.S.A., 'The Most Entrepreneurial and Innovative Universities Index' in Turkey are some of the measurement tools for ranking the most entrepreneurial universities. In Turkey, the Scientific and Technological Research Council of Turkey (TUBITAK) initiated an index to measure the 50 most entrepreneurial and innovative universities annually. Classifying universities according to their entrepreneurship levels is a new concept in Turkey that has found an important place on the agendas of various stakeholders, including university management executives, policymakers, academics, and students since its introduction in 2012 by TUBITAK. Ranking the performances of universities over the years aims to foster the competitiveness based on entrepreneurial and innovativeness activities among Turkish universities. The most entrepreneurial and innovative universities index (i.e., EIUI) is composed of four criteria and several indicators, as given in Table A.1 in the Appendix. 
The data for indicators are provided by several institutions, as illustrated in the last column of Table A.1, including the Ministry of Industry and Technology, TUBITAK, Council of Higher Education, Turkish Patent and Trademark Office, and Small and Medium Enterprises Development Organization of Turkey. Nineteen different indicators reflect the four main criteria that are listed in the first column of Table A.1. Some indicators count the number of scientific papers, citations, and doctoral graduates to assess the research performance in a typical university ranking index, such as U.K.'s Times Higher Education (THE) rankings or Quacquarelli Symonds' (Q.S.) World University Rankings. Some other indicators focus on companies owned or partnered by graduates or students, similar to the Princeton Review's annual rankings of top universities for entrepreneurship. TUBITAK's EIUI also includes other indicators mainly focusing on the innovativeness of the university measuring the number of patent and utility model applications, and the R\&D and innovation projects carried out by university, industry, and international cooperation.

Ranking the universities according to the indicators given in Table A.1 in the year 2018 results in Table A.2 in the Appendix. The total scores range between 29.63 and 93.16, where the average total score is 53.29. When the scores for each criterion is normalized to 100 , the average scores are calculated as 56.34, 47.53, 60.19, and 47.63 for CSTR, IPR, CI, and ECC, respectively. The average criterion-based scores indicate that universities get lower scores in both Intellectual Property Pool and Economic Contribution and Commercialization measures (i.e., 47.53 and 47.63) relative to the other components. While the universities overall seem to be competent in scientific and technological research, transforming these assets into tangible outputs such as the number of patents or firms established by the students, graduates or academics appear to be low as compared to the other criteria of entrepreneurship and innovation. We also notice the change in the positions of the universities when the universities in the list are re-ranked according to the individual subcriterion components. Although the scores are totaled and weighed over subcomponents as shown in the last column of Table A.2, the breakdown of the total scores across subcomponents provides a good overview of the strong and weak areas in the path to becoming a more innovative and entrepreneurial university for all universities.

\subsubsection{The Performance Index for Technoparks}

The Bayh-Dole Act of 1980 in the U.S. had been designed and employed to facilitate the technology transfer from the universities to the industry, stimulating the patenting and licensing activities of American universities (Mowery et al. 2001). Similar actions also took place in Europe and all around the world to create and promote entrepreneurial universities (Kirby 2006). In Turkey, several initiatives were also taken on the path to developing entrepreneurial universities. The Turkish Government passed legislation to establish 85 technoparks within the country in 2001. Seventy-one of these planned eighty-five technoparks were established, and they are active as of 2020. The technoparks are also called technology development zones with geographical locations, as shown in Figure 1. Technoparks are targeted to be made attractive to entrepreneurs with the support and incentives provided by the government (Cansiz 2017).

As of October 2020, 6,119 firms operate at these technoparks. 322 of these are foreign firms or have foreign partners, 1,289 of them have academic partners. These firms completed 37,605 projects, with 10,484 more in progress. Various intellectual and industrial property rights have been granted at these technoparks (Table 1).

While the numbers of intellectual and industrial property, as shown in Table 1, reflect the success and performance of these technoparks, establishing a comprehensive performance index for technoparks or science parks is not an easy task. As an example, Bigliardi et al. (2006) identify several areas of performance, including economic and financial aspects, human resources, and technical-scientific productivity, as well as international and inter-regional relationship development in measuring the success of science parks. Berbegal-Mirabent et al. (2019) draw attention to how the objectives and strategies of a science park might affect its performance, such that focusing on a few relevant components in mission statements might result in higher performance.

In Turkey, the Ministry of Industry and Technology developed an index to measure 


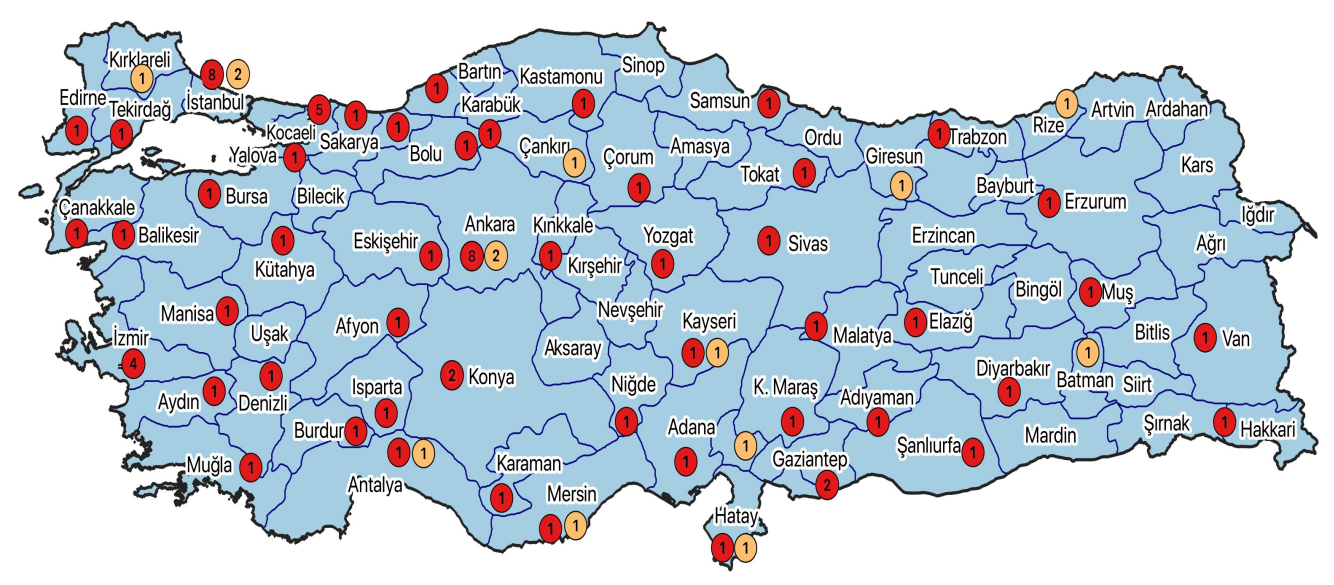

Figure 1: Technoparks in Turkey: Red and yellow circles denote the active and inactive technoparks, respectively

Table 1: Intellectual and Industry Property at Technoparks

\begin{tabular}{lr}
\hline Intellectual and Industry Property & Count \\
\hline Number of patent registrations (National/International) & 1,239 \\
Number of patent applications (in progress) & 2,793 \\
Number of utility model registrations & 431 \\
Number of utility model applications (in progress) & 261 \\
Number of industrial design registrations & 181 \\
Number of industrial design applications (in progress) & 122 \\
Software copyright (acquired) & 419 \\
\hline
\end{tabular}

Source: https://btgm.sanayi.gov.tr

the performances of technoparks, which we refer to as the Technopark Performance Index (TPI) within the context of this study. The index is employed every year starting from 2011 and monitors the performances of technoparks relative to each other over the years. Thus, the Ministry aims to provide the necessary support to technoparks in achieving its target $R \& D$ and innovation levels by revealing their strong and weak areas of performance and relative positions among all technoparks. Tracking the performance of technoparks via the index also gives direction to decisionmakers in drawing future strategies for the growth of the universities and the overall economy. The proximity of technoparks to universities is shown to positively affect university growth by shifting academic research from basic to applied (Link, Scott 2003). Technoparks' performance, on the other hand, bolsters economic diversity and jobs (Dabrowska 2011). The policymakers can align the interests of both the university and the technopark in the direction of specialized fields with the highest performance.

The index is composed of 25 different indicators targeting to measure three main criteria of performance - Inputs, Activities, and Outputs - as shown in Table A.3 in the Appendix. The subcriteria of the Inputs are measures of Financing, Incentives, and Infrastructure, where they are altogether weighed as $16.67 \%$. Activities are formed of five different subcriteria that are R\&D Activities, Incubation Activities, Technology Transfer \& Collaboration, Institutionalization, Sustainability and Developing Ecosystems, and Technology Product Investment. Activities have the highest weight, with $51 \%$ on the overall score of performance. Lastly, the criterion Outputs consists of indicators measuring three subcomponents that are R\&D Outputs, Intellectual Property, R\&D Impact, and Internationalization with a weight of $32.33 \%$ on the overall performance score.

The performances of technoparks are ranked according to their scores as measured by the performance indicators given in Table A.3. The rankings of all technoparks in the year 2018, the same as the year that EIUI was measured, are provided in Table A.4 in the 


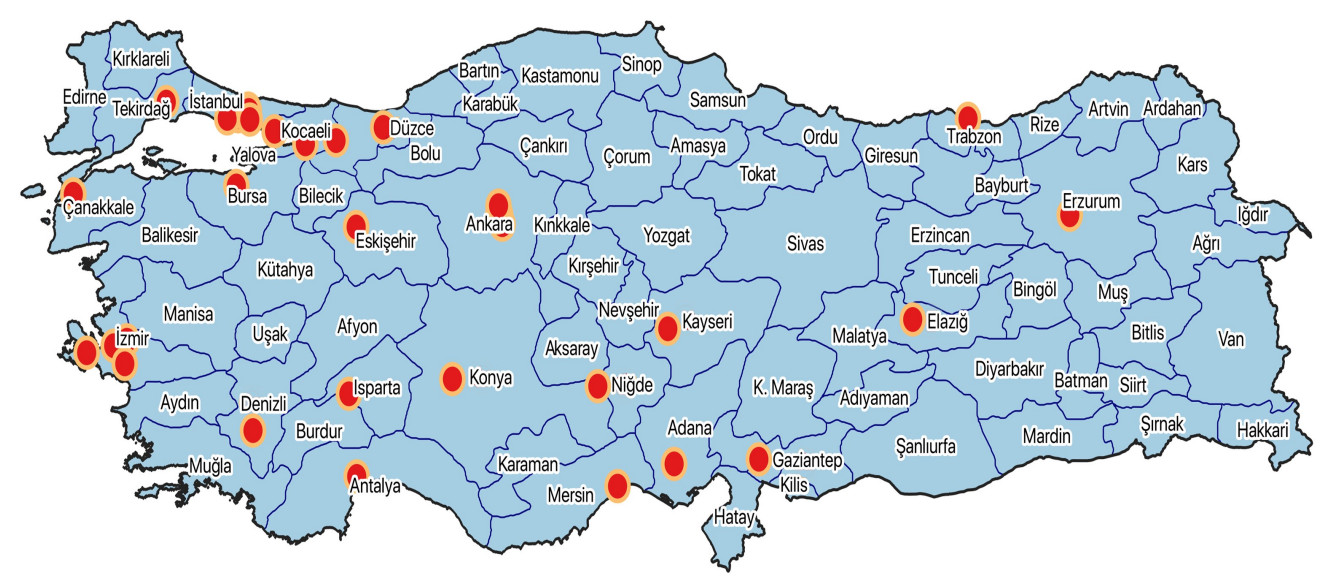

Figure 2: The geographical distribution of the 34 technoparks that are used in empirical analyses

Table 2: Descriptive Statistics and the Correlation Matrix of the Model Variables

\begin{tabular}{lccccccc}
\hline & EIUI & TPI & $\begin{array}{c}\text { Technopark } \\
\text { Age }\end{array}$ & $\begin{array}{c}\text { University } \\
\text { Age }\end{array}$ & $\begin{array}{c}\text { University } \\
\text { Size }\end{array}$ & $\begin{array}{c}\text { Log } \\
\text { GradStudent }\end{array}$ & SEGE \\
\hline EIUI & 1 & & & & & & \\
TPI & $-0.631^{* *}$ & 1 & & & & & \\
Technopark Age & $0.485^{* *}$ & $-.547^{* *}$ & 1 & & & & \\
University Age & $0.425^{*}$ & $-.360^{*}$ & 0.301 & 1 & & & \\
University Size & -0.297 & 0.098 & -0.126 & $0.395^{*}$ & 1 & & \\
LogGradStudent & $0.397^{*}$ & -0.334 & 0.269 & $0.992^{* *}$ & $0.465^{* *}$ & 1 & 1 \\
SEGE & $0.739^{* *}$ & $-0.349^{*}$ & 0.159 & 0.321 & -0.202 & 0.336 & 1.69 \\
Mean & 56.94 & 22.71 & 11.76 & 39.76 & 10.53 & 8.60 & 1.43 \\
Std. Dev. & 18.44 & 14.29 & 3.89 & 17.95 & 0.72 & 0.83 & -0.53 \\
Min. & 31.69 & 1 & 4 & 12 & 8.55 & 6.52 & 4.05 \\
Max. & 93.16 & 49 & 17 & 85 & 11.36 & 9.96 & \\
\hline
\end{tabular}

$*, * *$ Correlation is significant at the 0.05 and 0.01 level (2-tailed).

Appendix. The date of establishment and the associated university are also given. The oldest technopark in the rankings was established in 2001, and there are a few technoparks established every other year between 2001 and 2015.

\subsection{Empirical Analyses}

When two indices are merged, 34 technoparks in the list of TPI are found to be associated with a single university in the list of EIUI in the same year, 2018. Thus, the dataset for the analyses is composed of these 34 universities. The universities are scattered around the country in 22 different cities. There exist more than one university-technopark couple in only three cities. There are 6, 5, and 4 universities in the cities Istanbul, Ankara, and Izmir, respectively. The distribution of the 34 technoparks across the country is shown in Figure 2.

The best performing universities data are supported with additional data on variables such as the age of technopark, the age of the university, the total number of students, the ratio of graduate students to all students, and the socio-economic development index that are obtained from the Council of Higher Education and the Ministry of Industry and Technology. The descriptive statistics and the correlation matrix of all variables are presented in Table 2.

The average age of the technoparks is 11.76 , where the minimum and maximum age is 4 and 17, respectively. On the other hand, the average age of universities is 39.76, where the oldest and youngest universities are 85 and 12 years old. The average score of EIUI is 56.94 ranging in the interval between 31.69 and 93.16 . We use the total number of students as a proxy for the university size; thus, this variable is constructed as the 
natural logarithm of the total number of students. Because of the large deviations in the total number of students and the ratio of graduate students to all students, we employ the logarithm of these variables and present the descriptive statistics for the transformed variables in Table 2. The average for the total number of students is found to be 44,778 , where the smallest size university has 5,172 , and the largest size university has 85,520 students. The average ratio of graduate students, including students that are at both masters and doctorate levels to all students, is 0.16 , which changes in the range between 0.06 and 0.33 . Lastly, the variable SEGE represents the development of the region related to social, economic, cultural, and environmental issues. SEGE scores are calculated annually. For our analyses, we use 2017 scores, which is the closest year to 2018. SEGE scores of the cities that the university-technopark couple reside in change between -0.53 and 4.05, which corresponds to cities Istanbul and Erzurum, respectively.

We run two different regression models to test the effects of the explanatory variables described in Table 2 on the dependent EIUI. The first model is the main effects model where we test the direct effects of the rank TPI, the age of technopark, the age of university, size of the university, the graduate student composition, and the SEGE on EIUI. The establishment and growth of graduate programs offering education in higher degrees and producing scientific knowledge take time. Thus, to test how these two variables, i.e., graduate student composition and the university-age, interact on the dependent EIUI, we add the two variables' multiplication to the first model. This gives us the second model, where we refer to the interaction effects model with the newly included interaction term. The parameter estimates of the ordinary least-squares regression models for both are presented in Table 3 .

The high adjusted coefficients of multiple determination for both models highlight the good fit of the models to the data. In the main effects model, TPI, university size, and SEGE are found to significantly affect the entrepreneurship and innovation related scores of the universities. The coefficient for TPI is negative and significant, pointing to the importance of climbing up in the technopark rankings on the scores of universities being more entrepreneurial and innovative. The university size, on the other hand, is found to have a reverse effect on EIUI. The negative and significant coefficient of university size indicates that smaller universities obtain higher scores of EIUI. SEGE is the third variable for which its effects are significant, implying the higher the SEGE scores of the city, the higher the scores of EIUI. The ages of the technopark and the university are found not to have any significant effects on EIUI.

While the university's composition of graduate students does not appear to be significant in the main effects model, the interaction effects of the ratio of graduate students to all students with the university age happen to be significant when both variables are present in the model. The direct effects of the ratio of graduate students to all are positive and significant. The larger the share of the graduate students (that are at master's and Ph.D. levels) to all students, the higher the university obtains a score as measured by EIUI. However, its interaction with the university age is negatively significant, revealing that the younger universities benefit more from the higher composition of graduate students among all students. The significant effects of TPI, the university size, and SEGE remain the same considering the direction of effects in the second model.

\section{Discussions and Concluding Remarks}

Entrepreneurial universities have emerged via the second academic revolution, which transformed the traditional university missions of teaching and research into new missions of economic and social development (Etzkowitz 2003). For so long, universities have transformed and organized their functions to translate the knowledge they produce into the economic activities that benefit the regions in which they reside (Clark 1998). The university arranges the innovation activities providing an entrepreneurial structure in the form of technology transfer offices, incubators, and technoparks (Dalmarco et al. 2018). Technoparks function as a key mechanism in the triple helix of university, industry, and government in creating and strengthening the entrepreneurial capacities of the university and the region. The extant literature has focused on the issues linking technoparks to 
Table 3: Parameter Estimates for the Dependent most Entrepreneurial and Innovative Universities Index

\begin{tabular}{|c|c|c|c|c|}
\hline & \multicolumn{2}{|c|}{ Main Effects Model } & \multicolumn{2}{|c|}{ Interaction Effects Model } \\
\hline & Unstd. Coeff. & Std. Coeff. & Unstd. Coeff. & Std. Coeff. \\
\hline Intercept & 116.865 & & 43.060 & \\
\hline TPI & -0.366 & $\begin{array}{c}-0.283 \\
(0.016)^{*}\end{array}$ & -0.336 & $\begin{array}{l}-0.260 \\
(0.019)\end{array}$ \\
\hline Technopark Age & 0.680 & $\begin{array}{c}0.143 \\
(0.192)\end{array}$ & 0.582 & $\begin{array}{c}0.123 \\
(0.234)\end{array}$ \\
\hline University Age & 0.127 & $\begin{array}{c}0.124 \\
(0.327)\end{array}$ & 2.618 & $\begin{array}{c}2.548 \\
(0.030)\end{array}$ \\
\hline University Size & -13.983 & $\begin{array}{l}-0.544 \\
(0.017)\end{array}$ & -12.279 & $\begin{array}{l}-0.478 \\
(0.026)\end{array}$ \\
\hline LogGradStudent & 8.582 & $\begin{array}{c}0.388 \\
(0.102)\end{array}$ & 14.504 & $\begin{array}{c}0.656 \\
(0.013)\end{array}$ \\
\hline $\begin{array}{l}\text { University Age } \times \\
\text { LogGradStudent }\end{array}$ & & & -0.272 & $\begin{array}{l}-2.653 \\
(0.037)\end{array}$ \\
\hline SEGE & 5.163 & $\begin{array}{c}0.401 \\
(0.002)\end{array}$ & 6.354 & $\begin{array}{c}0.493 \\
(0.000)\end{array}$ \\
\hline Adj. $R^{2}$ & & & & \\
\hline
\end{tabular}

*p-values are given in parentheses

knowledge spillovers to firms (Díez-Vial, Fernández-Olmos 2015, Montoro-Sánchez et al. 2011); however, how universities benefit from the proximity of technoparks is an area which requires further questioning. We explore the link between entrepreneurial universities and technoparks from a regional perspective considering the university region-specific factors.

The most entrepreneurial and innovative universities index is an initiative that was developed by the government in Turkey and has been successful in creating a competitive environment amongst the universities towards realizing the third mission. While the performance of the entrepreneurial universities has been measured for more than eight years now, there is little known about which ways the universities benefit in the path towards being more entrepreneurial. We empirically analyze a cross-section of the most recent data on the two indices of EIUI and TPI to understand which specific characteristics play a role in the increasing performances of the entrepreneurial universities.

Our findings highlight the importance of the performance of the technopark the university is linked to the university's scores on entrepreneurship and innovativeness. The higher the rankings in technopark performance, the more the university achieves in entrepreneurship and innovation. This finding may look like the expected outcome when one thinks of the connection between the activities and outputs measured in technoparks rankings to the collaboration, economic contribution, and commercialization dimensions in entrepreneurial universities rankings. However, in combining the two indices, the universities that are associated with 16 of technoparks out of the best 50 are not placed in the most entrepreneurial universities list. While our findings reveal the link between the two based on empirical evidence, there are certainly other characteristics that promote the entrepreneurial levels of universities.

University size happens to be a significant characteristic that inversely contributes to the university's ranking of entrepreneurship and innovativeness. Measuring the university size in the total number of students enrolled, we find that the smaller the size of the university, the more the university performs in entrepreneurship and innovation. The most entrepreneurial universities in the U.S., according to the Princeton Review's annual evaluation between 2015 and 2018, reveal that the average number of students enrolled at these universities is approximately 27,500 , which are considered to be small universities (Özer et al. 2019). Rubens, Spiragelli (2017) argue that small universities adopt a more 
regional approach in achieving the third mission. Universities that are smaller in size are, in general, more agile and could respond to the changes faster as compared to the massively scaled universities where the management can be more complex.

Two other university-specific characteristics are found to interact with each other, which makes the interpretation more interesting, considering the context of the study. The direct effects for the student composition measured as the relative ratio of the graduate students to all students and the university age are found to be positively significant in the interaction effects model. However, their joint effect is significantly negative, indicating that younger universities benefit more from the higher composition of graduate students among all students. The other factors, including technoparks' rankings, university size, and socio-economic development index, continue to remain in the model with the same direction in their effects as before. The high graduate student ratio points to the better research productivity, which the prior literature identifies as a quality of research universities in their contributions to local knowledge spillovers and entrepreneurship activities (Smith, Bagchi-Sen 2012). Our findings suggest that this effect could be more viable for younger universities, which implies the role of small specialized universities in regional development and innovation.

Measuring the performances of entrepreneurial universities in quantitative metrics has been new for regional economies. Considering the universities' battle for bringing about the third mission, our study offers different avenues for future thinking of the university-technopark links in regional innovation and entrepreneurship. Our analyses are cross-sectional since the methodology of the rankings has changed as of 2018, which limits the number of periods to study. However, future studies can extend the analyses to longitudinal ones within different regional contexts. Besides, future case studies will help to provide an in-depth understanding of how entrepreneurial universities benefit from being associated with technoparks. Having access to information on some regional characteristics such as human capital of the region, industrial infrastructure of the region, $\mathrm{R} \& \mathrm{D}$ investments, and other regional development measures could take the analyses to a higher state.

\section{Acknowledgement}

Earlier versions of this study were presented at the $58^{\text {th }}$ European Regional Science Association (ERSA) Congress, Cork University, Ireland (August 2018), and at the $18^{\text {th }}$ National Regional Science and Planning Congress, Marmara University, Istanbul, Turkey (May 2018).

\section{References}

Agrawal A (2001) University-to-industry knowledge transfer: Literature review and unanswered questions. International Journal of Management Reviews 3: 285-302. CrossRef.

Albahari A, Barge-Gil A, Pérez-Canto S, Modrego A (2018) The influence of science and technology park characteristics on firms' innovation results. Papers in Regional Science 97: 253-279. CrossRef.

Albahari A, Pérez-Canto S, Barge-Gil A, Modrego A (2017) Technology parks versus science parks: Does the university make the difference? Technological Forecasting and Social Change 116: 13-28. CrossRef.

Audretsch DB (2002) The innovative advantage of US cities. European Planning Studies 10: 165-176. CrossRef.

Audretsch DB, Feldmann M (2007) R\&D spillovers and the geography of innovation and production. The American Economic Review 86: 630-640

Audretsch DB, Hülsbeck M, Lehmann EE (2012) Regional competitiveness, university spillovers, and entrepreneurial activity. Small Business Economics 39: 587-601. CrossRef. 
Baycan T, Stough RR (2013) Bridging knowledge to commercialization: The good, the bad, and the challenging. Annals of Regional Science 50: 367-405. CrossRef.

Bengtsson L, Nilsson AS, Rickne A (2009) Why and how do researchers engage themselves in commercialization of research? International conference on Organizational Learning, Knowledge and Capabilities (OLKC) 26-28 April 2009, Amsterdam, The Netherlands

Benneworth P, Pinheiro R, Sánchez-Barrioluengo M (2016) One size does not fit all! New perspectives on the university in the social knowledge economy. Science and Public Policy 43: 731-735. CrossRef.

Berbegal-Mirabent J, Alegre I, Guerrero A (2019) Mission statements and performance: An exploratory study of science parks. Long range planning. CrossRef.

Bercovitz J, Feldmann M (2006) Entrepreneurial universities and technology transfer: A conceptual framework for understanding knowledge-based economic development. Journal of Technology Transfer 31: 175-188. CrossRef.

Betts JR, Lee CWB (2004) Universities as drivers of regional and national innovation: An assessment of the linkages from universities to innovation and economic growth. Conference Higher Education in Canada, John Deutsch Institute Conference, Queens University, Kingston, ON, 1-59

Bigliardi B, Dormio AI, Nosella A, Petroni G (2006) Assessing science parks' performances: Directions from selected Italian case studies. Technovation 26: 489-505. CrossRef.

Boh WF, De-Haan U, Strom R (2016) University technology transfer through entrepreneurship: Faculty and students in spinoffs. Journal of Technology Transfer 41: 661-669. CrossRef.

Bok D (2003) Universities in the market place: The commercialization of higher education. Princeton University Press, Princeton NJ

Boschma RA (2005) Proximity and innovation: A critical assessment. Regional Studies 39: 61-74. CrossRef.

Boucher G, Conway C, van Der Meer E (2003) Tiers of engagement by universities in their region's development. Regional Studies 37: 887-897. CrossRef.

Bramwell A, Wolfe DA (2008) Universities and regional economic development: The entrepreneurial University of Waterloo. Research Policy 37: 1175-1187. CrossRef.

Budyldina N (2018) Entrepreneurial universities and regional contribution. International Entrepreneurship and Management Journal 14: 265-277. CrossRef.

Cansiz M (2017) 2023'e DoğruTürkẏe Teknoparklari. Retrieved from the T.C. Kalkınma Bakanlığı website https://sbb.gov.tr/wp-content/uploads/2018/11/2023e_Dogru_TUrkiye_Teknoparklari.pdf on November 16, 2020

Carayannis EG, Campbell DFJ (2010) Triple helix, quadruple helix and quintuple helix and how do knowledge, innovation and the environment relate to each other? A proposed framework for a trans-disciplinary analysis of sustainable development and social ecology. International Journal of Social Ecology and Sustainable Development 1: 41-69. CrossRef.

Charles D, Howells D (1992) Technology transfer in Europe: Public and private networks. Belhaven Press, London

Clark BR (1983) The Higher Education System: Academic Organization in Cross-National Perspective. University of California Press, Oakland, CA

Clark BR (1998) Creating Entrepreneurial Universities. Organizational Pathways of Transformation. Pergamon Press, Oxford 
Dabrowska J (2011) Measuring the success of science parks: performance monitoring and evaluation. XXVIII IASP World Conference on Science and Technology Parks, 1-23. http://www.pmf.sc.gov.br/arquivos/arquivos/pdf/08_07_2011_16.28.06.346a693b4baaca30ad620164d8186c1d.pdf

Dalmarco G, Hulsink W, Blois GV (2018) Creating entrepreneurial universities in an emerging economy: Evidence from Brazil. Technological Forecasting and Social Change 135: 99-111. CrossRef.

Díez-Vial I, Fernández-Olmos M (2015) Knowledge spillovers in science and technology parks: How can firms benefit most? Journal of Technology Transfer 40: 70-84. CrossRef.

Díez-Vial I, Montoro-Sánchez A (2016) How knowledge links with universities may foster innovation: The case of a science park. Technovation 50-51: 41-52. CrossRef.

Duch-Brown N, García-Estévez J, Parellada-Sabata M (2011) Universities and regional economic growth in Spanish regions. Institut d'Economia de Barcelona (IEB)

Eckhardt JT, Shane SA (2003) Opportunities and entrepreneurship. Journal of Management 29: 333-349. CrossRef.

Etzkowitz H (1983) Entrepreneurial scientists and entrepreneurial universities in American academic science. Minerva 21: 198-233. CrossRef.

Etzkowitz H (1990) The capitalization of knowledge: The decentralization of United States industrial and science policy from Washington to the States. Theory and Society 19: 107-121

Etzkowitz H (2002) Bridging knowledge to commercialization: The American way. Science Policy Institute, State University of New York

Etzkowitz H (2003) Research groups as "quasi-firms": The invention of the entrepreneurial university. Research Policy 32: 109-121. CrossRef.

Etzkowitz H (2004) The evolution of the entrepreneurial university. International Journal of Technology and Globalisation 1: 64-77. CrossRef.

Etzkowitz H (2016) Innovation lodestar: The entrepreneurial university in a stellar knowledge firmament. 16: 122-129. CrossRef.

Etzkowitz H, Leydesdorff L (1995) The triple helix: University-industry-government relations: A laboratory for knowledge based economic development. EASST Review 14: 14-19

Etzkowitz H, Webster A, Gebhardt C, Terra BRC (2000) The future of the university and the university of the future: Evolution of ivory tower to entrepreneurial paradigm. Research Policy 29: 313-330. CrossRef.

Fan CC, Scott AJ (2003) Industrial agglomeration and development: A survey of spatial economic issues in East Asia and a statistical analysis of Chinese regions. Economic Geography 79: 295-319. CrossRef.

General Directorate of Legislation Development (2001) The official gazette 2001. General directorate of legislation development. Retrieved from the official gazette website: https://www.resmigazete.gov.tr/eskiler/2001/07/20010706.htm on November 16, 2020,

Goldfarb B, Henrekson M (2003) Bottom-up versus top-down policies towards the commercialization of university intellectual property. Research Policy 32: 639-658. CrossRef.

Goldstein HA, Renault CS (2004) Contributions of universities to regional economic development: A quasi-experimental approach. Regional Studies 38: 733-746. CrossRef. 
Gunaseka ra C (2006) Reframing the role of universities in the development of regional innovation systems. Journal of Technology Transfer 31: 101-113. CrossRef.

Hannon PD (2013) Letter from academia why is the entrepreneurial university important? Journal of Innovation Management 1: 10-17. CrossRef.

Huang KF, Yu CMJ, Seetoo DH (2012) Firm innovation in policy-driven parks and spontaneous clusters: The smaller firm the better? Journal of Technology Transfer 37: 715-731. CrossRef.

Hudson C (2006) Regional development partnerships in Sweden: A way for higher education institutions to develop their role in the processes of regional governance? Higher Education 51: 387-410. CrossRef.

Jacob M, Lundqvist M, Hellsmark H (2003) Entrepreneurial transformations in the Swedish university system: The case of Chalmers University of Technology. Research Policy 32: 1555-1568. CrossRef.

Jensen BR, Thursby M (2016) American economic association proofs and prototypes for sale: The licensing of university inventions. The American Economic Review 91: 240-259. CrossRef.

Jongwanich J, Kohpaiboon A, Yang CH (2014) Science park, triple helix, and regional innovative capacity: Province-level evidence from China. Journal of the Asia Pacific Economy 19: 333-352. CrossRef.

Kirby DA (2006) Creating entrepreneurial universities in the UK: Applying entrepreneurship theory to practice. Journal of Technology Transfer 31: 599-603. CrossRef.

Kochetkov DM, Larionova VA, Vukovic DB (2017) Entrepreneurial capacity of universities and its impact on regional economic growth. Ekonomika Regiona - Economy of Region 13: 477-488. CrossRef.

Kuttim M (2016) The role of spatial and non-spatial forms of proximity in knowledge transfer: A case of technical university. European Journal of Innovation Management 19: 468-491. CrossRef.

Lazzeretti L, Tavoletti E (2005) Higher education excellence and local economic development: The case of the entrepreneurial University of Twente. European Planning Studies 13: 475-493. CrossRef.

Leydesdorff L, Etzkowitz H (1996) Conference report university-industry-government relations. Science and Public Policy 23: 279-286

Löfsten H, Lindelöf P (2003) Determinants for an entrepreneurial milieu: Science parks and business policy in growing firms. Technovation 23: 51-64. CrossRef.

Liberati D, Marinucci M, Tanzi GM (2016) Science and technology parks in Italy: Main features and analysis of their effects on the firms hosted. Journal of Technology Transfer 41: 694-729. CrossRef.

Lindelöf P, Löfsten H (2002) Science parks and the growth of new technology-based firms - academic-industry links, innovation and markets. Research Policy 30: 143-154. CrossRef.

Link AN, Scott JT (2003) U.S. science parks: The diffusion of an innovation and its effects on the academic missions of universities. Universities and the Entrepreneurial Ecosystem 21: 3-36. CrossRef.

Link AN, Scott JT (2007) The economics of university research parks. Oxford Review of Economic Policy 23: 661-674. CrossRef. 
Litan R, Mitchell L, Reedy EJ (2008) Commercializing university innovations: Alternative approaches. In: Innovation Policy and the Economy, Volume 8. National Bureau of Economic Research, Inc https://EconPapers.repec.org/RePEc:nbr:nberch:5301, 31-57

Louis KS, Blumenthal D, Gluck ME, Stoto MA (1989) Entrepreneurs in academe: An exploration of behaviors among life scientists. Administrative Science Quarterly 34: 110-131. CrossRef.

Malairaja C, Zawdie G (2008) Science parks and university-industry collaboration in Malaysia. Technology Analysis and Strategic Management 20: 727-739. CrossRef.

Melese T (2006) Building and managing corporate alliances in an academic medical center. Research Management 15: 1-9

Monck CSP, Porter RB, Quintas P, Storey DJ, Wynarczyk P (1988) Science Parks and the Growth of High Technology Firms. Croom Helm, London

Montoro-Sánchez A, Ortiz-de Urbina-Criado M, Mora-Valentín EM (2011) Effects of knowledge spillovers on innovation and collaboration in science and technology parks. Journal of Knowledge Management 15: 948-970. CrossRef.

Mowery DC, Nelson RR, Sampat BN, Ziedonis AA (2001) The growth of patenting by American universities: An assessment of the Bayh-Dole Act of 1980. Research Policy 30: 99-119. CrossRef.

Nilsson AS, Rickne A, Bengtsson L (2010) Transfer of academic research: Uncovering the grey zone. Journal of Technology Transfer 35: 617-636. CrossRef.

Özer M, Güder A, Arkalı Olcay G (2019) How do entrepreneurial universities contribute to regional development and innovation? In: Corpakis D, Ketikidis P (eds), European Triple Helix Congress on Responsible Innovation $\&$ Entrepreneurship. South East European Research Centre

Power D, Malmberg A (2008) The contribution of universities to innovation and economic development: In what sense a regional problem. Cambridge Journal of Regions, Economy and Society 1: 233-245. CrossRef.

Quintas P, Wield D, Massey D (1992) Academic-industry links and innovation: Questioning the science park model. Technovation 12: 161-175. CrossRef.

Rasmussen E, Moen O, Gulbrandsen M (2006) Initiatives to promote commercialization of university knowledge. Technovation 26: 518-533. CrossRef.

Rubens A, Spiragelli F (2017) Universities' third mission and the entrepreneurial university and the challenges they bring to higher education institutions. Journal of Enterprising Communities: People and Places in the Global Economy 11: 354-372. CrossRef.

Shane S, Stuart T (2002) Organizational endowments and the performance of university start-ups. Management Science 48: 154-170. CrossRef.

Siegel DS, Waldman DA, Atwater LE, Link AN (2004) Toward a model of the effective transfer of scientific knowledge from academicians to practitioners: Qualitative evidence from the commercialization of university technologies. Journal of Engineering and Technology Management 21: 115-142. CrossRef.

Siegel DS, Wright M (2015) Academic entrepreneurship: Time for a rethink? British Journal of Management 26: 582-595. CrossRef.

Smith HL, Bagchi-Sen S (2012) The research university, entrepreneurship and regional development: Research propositions and current evidence. Entrepreneurship and Regional Development 24: 383-404. CrossRef.

Sánchez-Barrioluengo M (2014) Articulating the "three-missions" in Spanish universities. Research Policy 43: 1760-1773. CrossRef. 
Sánchez-Barrioluengo M, Benneworth P (2019) Is the entrepreneurial university also regionally engaged? Analysing the influence of university's structural configuration on third mission performance. Technological Forecasting and Social Change 141: 206-218. CrossRef.

Torre A, Gilly JP (2000) On the analytical dimension of proximity dynamics. Regional Studies 34: 169-180. CrossRef.

van Geenhuizen M (2010) Patterns of knowledge commercialization at universities: Project level results in The Netherlands. Ersa conference, 19-23 august 2010, jonkoping, sweden

Viale R, Etzkowitz H (2010) The capitalization of knowledge: A triple helix of universityindustry government. Edward Elgar, Cheltenham

Vásquez-Urriago R, Barge-Gil A, Modrego Rico A (2016) Science and technology parks and cooperation for innovation: Empirical evidence from Spain. Research Policy 45: 137-147. CrossRef.

cc) (7) (8) (C) 2021 by the authors. Licensee: REGION - The Journal of ERSA, European

Regional Science Association, Louvain-la-Neuve, Belgium. This article is distri-

buted under the terms and conditions of the Creative Commons Attribution, Non-Commercial (CC BY NC) license (http://creativecommons.org/licenses/by-nc/4.0/). 


\section{A Appendix: Data for the Most Entrepreneur and Innovative Universities Index and Technopark Performance Index}

Table A.1: The Criteria and Indicators of the Most Entrepreneur and Innovative Universities Index

\begin{tabular}{|c|c|c|c|}
\hline Criterion & Weight & Indicators & Data Sources \\
\hline $\begin{array}{l}\text { Competency in } \\
\text { Scientific and } \\
\text { Technological } \\
\text { Research (CSTR) }\end{array}$ & $23.75 \%$ & $\begin{array}{l}\text { 1) Number of scientific papers } \\
\text { 2) Citations } \\
\text { 3) Number of projects received } \\
\text { from R\&D and innovation } \\
\text { support programs } \\
\text { 4) Amount of funds received from } \\
\text { R\&D and innovation support } \\
\text { programs } \\
\text { 5) Number of national and } \\
\text { international science awards } \\
\text { 6) Number of doctoral graduates }\end{array}$ & $\begin{array}{l}\text { TUBITAK, the Ministry of } \\
\text { Industry and Technology, the } \\
\text { Council of Higher Education, } \\
\text { Turkish Academy of Sciences, } \\
\text { Technology Development } \\
\text { Foundation of Turkey }\end{array}$ \\
\hline $\begin{array}{l}\text { Intellectual } \\
\text { Property Pool } \\
\text { (IPR) }\end{array}$ & $18.75 \%$ & $\begin{array}{l}\text { 7) Number of patent applications } \\
\text { 8) Number of patent documents } \\
\text { 9) Number of utility model/num- } \\
\text { ber of industrial design } \\
\text { documents } \\
\text { 10) Number of international } \\
\text { patent applications }\end{array}$ & $\begin{array}{l}\text { Turkish Patent Office, the } \\
\text { Council of Higher Education, } \\
\text { Universities }\end{array}$ \\
\hline $\begin{array}{l}\text { Collaboration and } \\
\text { Interaction (CI) }\end{array}$ & $28.75 \%$ & $\begin{array}{l}\text { 11) Number of } \mathrm{R} \& \mathrm{D} \text { and } \\
\text { innovation projects carried out } \\
\text { by university-industry } \\
\text { 12) Amount of funds received } \\
\text { from R\&D and innovation } \\
\text { projects carried out by university- } \\
\text { industry cooperation } \\
\text { 13) Number of R\&D and } \\
\text { innovation projects made with } \\
\text { international cooperation } \\
\text { 14) Amount of funds obtained } \\
\text { from international R\&D and } \\
\text { innovation collaborations } \\
\text { 15) Number of academic staff/ } \\
\text { students in circulation }\end{array}$ & $\begin{array}{l}\text { TUBITAK, the Ministry of } \\
\text { Industry and Technology, the } \\
\text { Council of Higher Education, } \\
\text { Technology Development } \\
\text { Foundation of Turkey, } \\
\text { Universities, Ministry of Foreign } \\
\text { Affairs Directorate for European } \\
\text { Union Affairs cooperation }\end{array}$ \\
\hline $\begin{array}{l}\text { Economic } \\
\text { Contribution and } \\
\text { Commercialization } \\
\text { (ECC) }\end{array}$ & $28.75 \%$ & $\begin{array}{l}\text { 16) Number of active firms } \\
\text { that are owned or partnered by } \\
\text { academics in technoparks and } \\
\text { incubation centers } \\
\text { 17) Number of active firms } \\
\text { that are owned or partnered } \\
\text { by university students or } \\
\text { graduates in the last five years } \\
\text { in technoparks and incubation } \\
\text { centers } \\
\text { 18) Number of people employed } \\
\text { by firms that are owned or } \\
\text { partnered by academics in } \\
\text { technoparks and incubators } \\
\text { 19) Number of patents / utility } \\
\text { models / industrial designs } \\
\text { licensed }\end{array}$ & $\begin{array}{l}\text { The Ministry of Industry and } \\
\text { Technology, the Council of } \\
\text { Higher Education, Small and } \\
\text { Medium Enterprises } \\
\text { Development Organization of } \\
\text { Turkey, Universities, TUBITAK, } \\
\text { Turkish Patent Office }\end{array}$ \\
\hline
\end{tabular}

Source: Created based on information at https://www.tubitak.gov.tr/ 
Table A.2: 2018 Rankings of Universities according to the most Entrepreneurial and Innovative Universities Index

\begin{tabular}{|c|c|c|c|c|c|c|}
\hline Rank & University & CSTR & IPR & CI & ECC & Total \\
\hline 1 & Middle East Technical University & 23.63 & 16.24 & 28.54 & 24.75 & 93.16 \\
\hline 2 & Istanbul Technical University & 21.93 & 15.89 & 27.59 & 24.75 & 90.16 \\
\hline 3 & Sabancı University & 18.08 & 15.16 & 27.9 & 24.36 & 85.49 \\
\hline 4 & Bilkent University & 21.3 & 14.02 & 26.05 & 23.05 & 84.42 \\
\hline 5 & Boğaziçi University & 20.55 & 15.46 & 28.06 & 19.26 & 83.33 \\
\hline 6 & Ylldız Technical University & 17.18 & 17.54 & 24.1 & 22.58 & 81.4 \\
\hline 7 & Gebze Technical University & 18.18 & 9.93 & 24.64 & 25.07 & 77.82 \\
\hline 8 & Hacettepe University & 20.18 & 12.51 & 24.44 & 18.8 & 75.93 \\
\hline 9 & Izmir Institute of Technology & 20.99 & 9.3 & 24.93 & 20.42 & 75.64 \\
\hline 10 & Ege University & 18.37 & 10.29 & 25 & 17 & 70.66 \\
\hline 11 & Koç University & 18.64 & 13.65 & 27.13 & 9.46 & 68.87 \\
\hline 12 & Istanbul University & 17.47 & 14.09 & 19.47 & 16.1 & 67.13 \\
\hline 13 & Gazi University & 18.07 & 10.69 & 19.3 & 18.74 & 66.8 \\
\hline 14 & Özyeğin University & 13.85 & 11.88 & 20.71 & 18.99 & 65.44 \\
\hline 15 & TOBB Economics and Technology University & 14.43 & 12.8 & 17.31 & 17.26 & 61.8 \\
\hline 16 & Dokuz Eylül University & 17.31 & 7.3 & 21.3 & 15.67 & 61.58 \\
\hline 17 & Erciyes University & 15.87 & 7.03 & 18.73 & 19.77 & 61.4 \\
\hline 18 & Ankara University & 18.77 & 5.44 & 22.06 & 13.63 & 59.9 \\
\hline 19 & Selçuk University & 14.97 & 13.58 & 15.64 & 13.72 & 57.91 \\
\hline 20 & Anadolu University & 11.54 & 10.4 & 16.16 & 18.89 & 56.99 \\
\hline 21 & Sakarya University & 12.1 & 9.76 & 15.34 & 18.55 & 55.74 \\
\hline 22 & Uludă̆ University & 11.52 & 11 & 16.74 & 15.27 & 54.53 \\
\hline 23 & Gaziantep University & 12.65 & 14.9 & 12.93 & 11.15 & 51.63 \\
\hline 24 & Akdeniz University & 13.92 & 8.45 & 18.85 & 9.89 & 51.11 \\
\hline 25 & Kocaeli University & 10.22 & 4.72 & 17.1 & 18.1 & 50.13 \\
\hline 26 & Atılım University & 10.21 & 5.37 & 14.91 & 17.14 & 47.63 \\
\hline 27 & Cukurova University & 14.43 & 5.88 & 16.42 & 8.74 & 45.47 \\
\hline 28 & Abdullah Gül University & 11.04 & 8.92 & 17.3 & 7.57 & 44.82 \\
\hline 29 & Istanbul Medipol University & 9.94 & 11.24 & 16.69 & 6.59 & 44.46 \\
\hline 30 & Süleyman Demirel University & 13.63 & 7.18 & 11.4 & 11.15 & 43.36 \\
\hline 31 & Yeditepe University & 11.74 & 15.73 & 15.82 & 0 & 43.29 \\
\hline 32 & Pamukkale University & 10.09 & 7.18 & 12.29 & 13 & 42.56 \\
\hline 33 & Marmara University & 14.85 & 5.04 & 17.88 & 3.97 & 41.73 \\
\hline 34 & Atatürk University & 16.75 & 6.29 & 11.01 & 6.94 & 41 \\
\hline 35 & Karadeniz Technical University & 12.83 & 3.8 & 13.39 & 10.81 & 40.83 \\
\hline 36 & Firat University & 10.94 & 5.38 & 9.43 & 14.77 & 40.52 \\
\hline 37 & İzmir Economy University & 6.43 & 10.07 & 14.23 & 8.97 & 39.7 \\
\hline 38 & Yaşar University & 7.96 & 5.98 & 13.35 & 11.23 & 38.53 \\
\hline 39 & Çankaya University & 8.79 & 6.39 & 11.75 & 10.88 & 37.81 \\
\hline 40 & Mersin University & 9.44 & 4.01 & 12.1 & 9.98 & 35.53 \\
\hline 41 & Eskişehir Osmangazi University & 11.8 & 3.53 & 10.43 & 8.84 & 34.6 \\
\hline 42 & Hasan Kalyoncu University & 4.49 & 11.25 & 5.87 & 12.58 & 34.19 \\
\hline 43 & Niğde Ömer Halisdemir University & 8.41 & 3.71 & 13.69 & 8.33 & 34.14 \\
\hline 44 & Bahçeşehir University & 8.61 & 1.95 & 14.05 & 9.36 & 33.97 \\
\hline 45 & Acıbadem Mehmet Ali Aydınlar University & 6.79 & 3.61 & 17.87 & 4.82 & 33.09 \\
\hline 46 & Başkent University & 6.18 & 4.92 & 7.68 & 13.8 & 32.59 \\
\hline 47 & Düzce University & 7.06 & 5.46 & 12.54 & 7.17 & 32.23 \\
\hline 48 & Çanakkale Onsekiz Mart University & 9.56 & 2.67 & 13.03 & 6.88 & 32.15 \\
\hline 49 & Tekirdağ Namık Kemal University & 7.14 & 3.18 & 8.49 & 12.88 & 31.69 \\
\hline 50 & İstanbul Şehir University & 8.2 & 4.82 & 13.6 & 3 & 29.63 \\
\hline
\end{tabular}

Source: https://www.tubitak.gov.tr/

CSTR: Competency in Scientific and Technological Research; IPR: Intellectual Property Pool; CI:

Collaboration and Interaction; $E C C$ : Economic Contribution and Commercialization 
Table A.3: Main and Sub-criteria of the Technopark Performance Index

\begin{tabular}{|c|c|c|c|}
\hline $\begin{array}{l}\text { Main } \\
\text { Criterion }\end{array}$ & Sub-criterion & $\begin{array}{l}\text { Percentage } \\
\quad(\%)\end{array}$ & Indicators \\
\hline Inputs & $\begin{array}{l}\text { Financing, Incentives, and } \\
\text { Infrastructure }\end{array}$ & 16.67 & $\begin{array}{l}\text { 1) Supports provided to the managing } \\
\text { company } \\
\text { 2) Occupancy level } \\
\text { 3) The exemption provided to firms } \\
\text { 4) Expenditures made by the managing } \\
\text { company }\end{array}$ \\
\hline \multirow[t]{5}{*}{ Activities } & R\&D Activities & 14 & $\begin{array}{l}\text { 5) } R \& D \text { staff } \\
\text { 6) } R \& D \text { expenditures } \\
\text { 7) } R \& D \text { projects }\end{array}$ \\
\hline & Incubation Activities & 9 & $\begin{array}{l}\text { 8) Incubation service } \\
\text { 9) Incubation employment }\end{array}$ \\
\hline & $\begin{array}{l}\text { Technology Transfer \& Col- } \\
\text { laboration }\end{array}$ & 13 & $\begin{array}{l}\text { 10) Knowledge and technology transfer } \\
\text { 11) Collaboration between firms } \\
\text { 12) International R\&D collaborations }\end{array}$ \\
\hline & $\begin{array}{l}\text { Institutionalization, Sus- } \\
\text { tainability and Developing } \\
\text { Ecosystems }\end{array}$ & 12 & $\begin{array}{l}\text { 13) Capacity building activity } \\
\text { 14) Services provided by the managing } \\
\text { company } \\
\text { 15) Clustering activities } \\
\text { 16) Overseas activities }\end{array}$ \\
\hline & $\begin{array}{l}\text { Technological Product In- } \\
\text { vestment }\end{array}$ & 3 & $\begin{array}{l}\text { 17) Investor activities } \\
\text { 18) Commercialization activities }\end{array}$ \\
\hline \multirow[t]{3}{*}{ Outputs } & R\&D Outputs & 6.67 & $\begin{array}{l}\text { 19) Project outputs } \\
\text { 20) Incubation service outputs }\end{array}$ \\
\hline & Intellectual Property & 5.99 & $\begin{array}{l}\text { 21) Patents } \\
\text { 22) Utility models } \\
\text { 23) Designs }\end{array}$ \\
\hline & $\begin{array}{l}\mathrm{R} \& \mathrm{D} \text { Impact and Interna- } \\
\text { tionalization }\end{array}$ & 19.67 & $\begin{array}{l}\text { 24) Export } \\
\text { 25) R\&D revenues }\end{array}$ \\
\hline
\end{tabular}

Source: Created based on information at https://www.btgm.sanayi.gov.tr/ 
Table A.4: 2018 Rankings of Technoparks according to their TPI

\begin{tabular}{|c|c|c|c|}
\hline Rank & Technopark & $\begin{array}{c}\text { Date of } \\
\text { Establishment }\end{array}$ & Associated University \\
\hline 1 & $\begin{array}{l}\text { Yıldız Technical University Techno- } \\
\text { park }\end{array}$ & 2003 & Yıldız Technical University \\
\hline 2 & $\begin{array}{l}\text { Middle East Technical University } \\
\text { Technopark }\end{array}$ & 2001 & Middle East Technical University \\
\hline 3 & $\begin{array}{l}\text { Istanbul Technical University Arı } \\
\text { Technopark }\end{array}$ & 2003 & Istanbul Technical University \\
\hline 4 & Ankara Technopark & 2002 & Bilkent University \\
\hline 5 & Mersin Technopark & 2005 & Mersin University \\
\hline 6 & Istanbul Technopark & 2009 & Istanbul Commerce University \\
\hline 7 & Erciyes University Technopark & 2004 & Erciyes University \\
\hline 8 & Batı Akdeniz Technopark & 2004 & Akdeniz University \\
\hline 9 & Izmir Technopark & 2002 & Izmir Institute of Technology \\
\hline 10 & $\begin{array}{l}\text { TUBITAK-Marmara } \quad \text { Research } \\
\text { Center Technopark }\end{array}$ & 2001 & TUBİTAK-TTGV \\
\hline 11 & Ankara University Technopark & 2006 & Ankara University \\
\hline 12 & Gazi Technopark & 2007 & Gazi University \\
\hline 13 & Trabzon Technopark & 2004 & Karadeniz Technical University \\
\hline 14 & Sakarya University Technopark & 2008 & Sakarya University \\
\hline 15 & Samsun Technopark & 2009 & Ondokuz Mayıs University \\
\hline 16 & Hacettepe University Technopark & 2003 & Hacettepe University \\
\hline 17 & Istanbul University Technopark & 2003 & Istanbul University \\
\hline 18 & Ege Technopark & 2014 & Ege University \\
\hline 19 & Ankara Technopark & 2014 & Yıldırım Beyazıt University \\
\hline 20 & GOSB Technopark & 2002 & Sabancı University \\
\hline 21 & Celal Bayar University Technopark & 2012 & Celal Bayar University \\
\hline 22 & $\begin{array}{l}\text { Namık Kemal University Techno- } \\
\text { park }\end{array}$ & 2011 & Tekirdağ Namık Kemal University \\
\hline 23 & Gaziantep Technopark & 2006 & Gaziantep University \\
\hline 24 & Selçuk University Technopark & 2003 & Selçuk University \\
\hline 25 & Dokuz Eylül Technopark & 2013 & Dokuz Eylül University \\
\hline 26 & Ulutek Technopark & 2005 & Bursa Uludağ University \\
\hline 27 & Konya Technopark & 2015 & $\begin{array}{l}\text { Selçuk, Necmettin Erbakan, } \\
\text { Aksaray Karamanoğlu Mehmet Bey, } \\
\text { KTO Karatay Universities }\end{array}$ \\
\hline 28 & Firat Technopark & 2007 & Firat University \\
\hline 29 & Erzurum Technopark & 2005 & Atatürk University \\
\hline 30 & Boğaziçi University Technopark & 2009 & Boğaziçi University \\
\hline 31 & Tokat Technopark & 2008 & Gaziosmanpaşa University \\
\hline 32 & Cumhuriyet Technopark & 2007 & Cumhuriyet University \\
\hline 33 & Kocaeli University Technopark & 2003 & Kocaeli University \\
\hline 34 & Pamukkale University Technopark & 2007 & Pamukkale University \\
\hline 35 & Eskişehir Technopark & 2003 & Anadolu University \\
\hline 36 & Kırıkkale University Technopark & 2013 & Kırıkkale University \\
\hline 37 & Kahramanmaraş Technopark & 2011 & Sütçü İmam University \\
\hline 38 & İzmir Science Technopark & 2012 & İzmir Economy University \\
\hline 39 & Düzce Technopark & 2010 & Düzce University \\
\hline 40 & Çukurova Technopark & 2004 & Çukurova University \\
\hline 41 & $\begin{array}{l}\text { Trakya University Edirne Techno- } \\
\text { park }\end{array}$ & 2008 & Trakya University \\
\hline 42 & Yüzüncü Yıl University Technopark & 2012 & Yüzüncü Yıl University \\
\hline 43 & Malatya Technopark & 2009 & İnönü University \\
\hline 44 & Çanakkale Technopark & 2011 & Çanakkale Onsekiz Mart University \\
\hline 45 & Göller Region Technopark & 2005 & Süleyman Demirel University \\
\hline 46 & Bolu Technopark & 2009 & Abant İzzet Baysal University \\
\hline 47 & Afyon Uşak Zafer Technopark & 2015 & Afyon Kocatepe, Uşak Universities \\
\hline 48 & $\begin{array}{l}\text { Niğde Ömer Halisdemir University } \\
\text { Technopark }\end{array}$ & 2013 & Niğde Ömer Halisdemir University \\
\hline 49 & Marmara University Technopark & 2014 & Marmara University \\
\hline 50 & Dicle University Technopark & 2007 & Dicle University \\
\hline
\end{tabular}

Source: Created based on information at https://www.btgm.sanayi.gov.tr/ 